\title{
AN EXPERIMENTAL MODEL FOR THE TRANSPLANTATION OF FETAL CENTRAL NERVOUS SYSTEM CELLS TO THE INJURED SPINAL CORD IN RATS
}

\author{
Tarcísio Eloy Pessoa de Barros Filho, Reginaldo Perilo de Oliveira, Ana Maria \\ Tsanaclis, Erika Meirelles Kalil Pessoa de Barros, Alexandre Fogaça Cristante, \\ Ricardo Moreira Palma, Cristian Vilela dos Santos and Raphael Martus Marcon
}

RHCFAP/3103

BARROS FILHO TEP de e col. - An experimental model for the transplantation of fetal central nervous system cells to the injured spinal cord in rats. Rev. Hosp. Clín. Fac. Med. S. Paulo 57(6):257-264, 2002.

INTRODUCTION: Traumatic spinal cord injury is one of the most disabling conditions occurring in man and thus stimulates a strong interest in its histopathological, biochemical, and functional changes, primarily as we search for preventive and therapeutic methods.

PURPOSE: To develop an experimental model for transplantation of cells from the fetal rat central nervous system to the site of an injured spinal cord of an adult rat in which the transplanted cells survive and become integrated. This experimental model will facilitate investigations of factors that promote regeneration and functional recovery after spinal cord trauma.

MATERIAL AND METHODS: Fifteen adult Wistar rats underwent laminectomy, and an spinal cord lesion was made with microdissection. Fetal spinal cord tissue was then transplanted to the site of the injury. The rats were monitored over a 48-hour period, and then their vertebral column was completely removed for histological analysis.

RESULTS: In $60 \%$ of transplanted rats, the fetal tissue at the injured site remained viable in the site of the lesion.

DESCRIPTORS: Spinal cord injury. Fetal cells. Rats.

\section{INTRODUCTION}

Spinal cord injury has been considered a condition without the possibility of successful treatment ${ }^{15}$. However, emerging studies in this field indicate that acute spinal cord injuries can be minimized by the use of pharmacologic therapy when drugs are administered within a short period of time following the trauma ${ }^{9,23,26,60}$. This progress is attributable largely to histological observations, which have facilitated better understanding of the sequence of events involved in the spinal cord injury ${ }^{10}$.

The first experiments focusing the pathophysiologic mechanism of the injured spinal cord were performed at the beginning of this century ${ }^{1,2}$. Nevertheless, these works were resumed only in the past decade by investigators who have begun to value the timedependent changes implicated in the physiopathology of spinal cord trauma $^{3,6,48}$.

The significant neurological deficit related to the spinal cord injury is caused by the sum of two different

From the Department of Orthopaedics and Traumatology, Hospital das Clínicas, Faculty of Medicine, University of São Paulo. conditions: the initial mechanical injury and the secondary endogenous injury resulting from the initial injury ${ }^{6,7,20,22,32,47,59,63}$. The primary damage is caused by the trauma itself and involves either cellular death or electrolyte, metabolite, and enzyme release. It is therefore a mechanical process that does not depend on cellular control mechanisms. The secondary injury of the spinal cord involves complex biochemical changes, which occur as a cascade of events such as swelling, inflammation, ischemia, reperfusion, the presence of growth factors, and calcium and lipidic peroxidase metabolism, and on which scientific ef- 
forts are based to reduce secondary injury $^{7,8,24,25,34,42,43,46,53,57,58,61,63}$. From a pharmacological standpoint, drugs that modulate the endogenous responses to the primary injury have been progressively introduced into therapeutic protocols to restrict the collateral damage and improve the potential for functional recovery of these patients. These drugs are administered to interrupt the pathophysiologic mechanisms of the secondary neuronal injury ${ }^{27,28,51}$.

Clinical and scientific advancements indicate that acutely injured spinal cords can be managed by pharmacological therapeutic procedures used within a short period of time. Methylprednisolone administered within the initial 8 hours after the trauma is the first pharmacological agent to promote significant improvement in the recovery of the injured spinal cord in human beings $\mathrm{s}^{4,11-14,19,35-}$ 40,52,56. Other drugs, such as tirilizad ${ }^{5}$, 39,41 and GM-1 18, 30, 31, 33, 49, 50, 64, which are still under clinical investigation, demonstrate promising preliminary results. These advancements should represent a significant improvement in the quality of life of patients with spinal cord injury once they are employed in current medical practice.

Central nervous system injuries are followed by a deficit condition and a period of variable functional recovery. Such recovery is strongly related to changes that involve unharmed circuits, although the exact mechanism of the recovery has not been completely clarified. Transplanting neural cells is helping investigators to understand the development of the CNS and its response to injuries. More recently, such transplants have been used to optimize the posttraumatic functional recovery. The specific mechanism through which such transplants act is not completely understood. Present theories posit the influence of trophic activity along with the release of hor- mones and neurotransmitters, and the re-enervation of host cells by the transplanted cells ${ }^{16}$. Current research is intended to determine the degree of recovery that can be achieved by these transplants.

The possibility of employing fetal nervous system cells for the treatment of a number of CNS pathologies has stimulated several studies on the physiology of the survival and integration of the transplant. Today it is known that transplanting fetal cells potentiates the locomotor recovery both in immature and adult individuals; However, the mechanism responsible for this observation is still unknown ${ }^{44}$

Several protocols for transplantation of fetal nervous system cells have been reported, but there is not a consensus among physicians on the best method ${ }^{44}$.

\section{OBJECTIVE}

The purpose of this study was to develop a reproducible method for transplanting cells from the fetal rat central nervous system to the site of an injured spinal cord of an adult rat that results in the survival and integration of the transplanted cells. Using this methodology, researchers will be able to study other factors that support regeneration and functional recovery of the posttraumatic spinal cord.

\section{MATERIALSAND METHODS}

\section{Model of an Injured Spinal Cord and Donor Tissue Preparation}

One male and two female rats were selected and put into 5 cages. After 12 hours, vaginal swabs from the female rats were taken and analyzed under optical microscopy to verify the presence of spermatozoids. The female rats whose vaginal swabs presented evidence of spermatozoids were considered pregnant and isolated in a different cage.

The donor tissue was obtained from fetal rats obtained by cesarean section on Day 14 of gestation. Immediately after the cesarean, each fetus had its central nervous system removed, which was inoculated into the injured spinal cord of the adult rats.

We analyzed the injuries from 15 rats initially, which were produced through hemilaminectomy at the T10 level and aspiration and delicate 05mm segment microdissection from the rat spinal cord.

The donor tissue was transplanted into the site of the injury using micropipettes, and it was then properly sutured.

The rats were sacrificed 48 hours following transplantation, and their spinal cords were surgically excised and submitted to histopathological analysis to verify the viability of the transplanted cells.

Rats

We used male and female Wistar rats aged 20 weeks and weighing 270 to $315 \mathrm{~g}$ and 200 to $280 \mathrm{~g}$ respectively, which were from a single supplier. They were acquired 1 week prior to the surgery to become acclimatized and manageable.

\section{Laminectomy}

The spinal cord was exposed through a laminectomy as follows:

- An opening was made in the median dorsal line of the skin to expose the vertebral column at T10 level (Fig. 1A) .

- The muscles inserted in the spinous processes from $\mathrm{T} 9$ to $\mathrm{T} 11$ level were sectioned and separated using a bipolar coagulant device to stop any bleeding if necessary.

The T10 vertebra and the distal half of the $\mathrm{T} 9$ spinous process were re- 
moved using a small punch. The removal began by the caudal edge of T10. Small fragments were delicately removed using the punch guided from the cranial to the caudal half of the sheath at the T9 level. (Fig. 1B). The spinal cord was not harmed (Fig. 2) .

The spinal cord injury procedure

- A $0.05 \mathrm{~mm}$ segment of one half of the medula of the rat was removed by aspiration and microdissection using a microscope.

- The rat was removed and placed on a warm surface. The contusion site was inspected. Any bleeding was stopped, and the contusion site was washed with a saline solution.

\section{Material for the transplantation}

The female rats underwent a cesarean section (Fig. 3A) . The fetuses were removed, and embryonic cells of the CNS were harvested with a microsurgical technique (Fig. 3B). The material that was obtained was obliquely sectioned into $0.05-\mathrm{mm}$ segments for transplanting into the injured site.
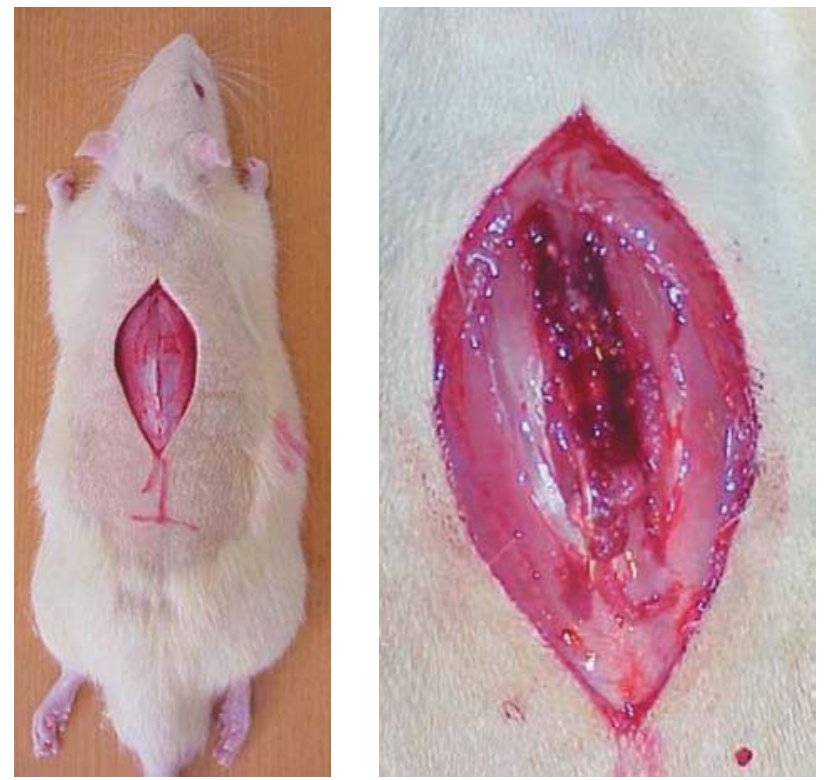

Figure 1 - A - Approach via to the vertebral column. B - Laminectomy.

Transplantation of fetal cells into the injured site

- The segment of the fetal CNS that was previously sectioned was implanted into the site of the injured spinal cord of adult rats.

- After the transplantation, the dural sac was closed using fibrin glue. Muscular, subcutaneous and cutaneous tissues were sutured.

\section{Posttraumatic procedures}

Over a 48-hour period following the injury, the rats were observed and had their deficits registered.

Euthanasia procedure and taking tissue samples for acute experiments

Euthanasia was performed 48 hours after surgery. The procedures for the euthanasia and the removal of tissue samples were as follows:

- 48 hours after the injury and transplantation, the rat body weight was registered at the time of sacrifice.

- The rat was anesthetized using pentobarbital $40 \mathrm{mg} / \mathrm{kg}$ given intravenously.

- The aorta of the rat was catheterized through thoracotomy to allow perfusion with paraformaldehyde solution.

- The vertebral column from C5 to L5 level and most of the muscles were quickly removed (Fig. 4).

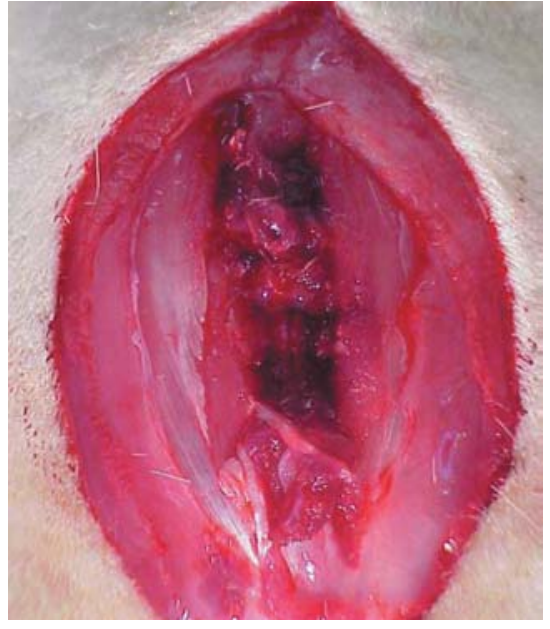

Figure 2 - Spinal cord exposure.

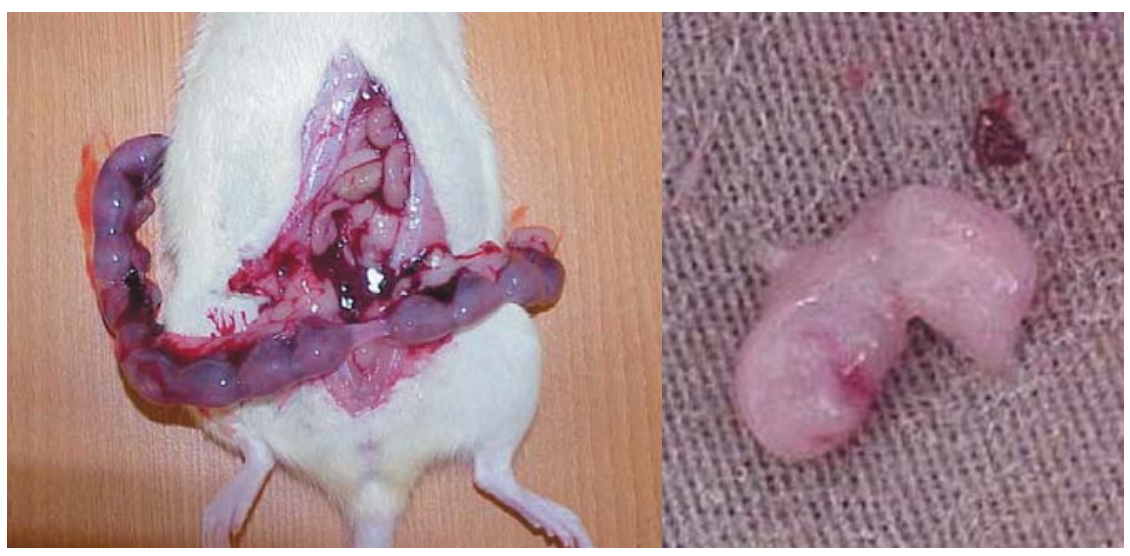

Figure 3 - A - Exposure of the pregnant uterus through cesarean section. B - Fetus. 
- The vertebral column was placed in a centrifuge, covered, and taped with Parafilm $^{\circledR}$.

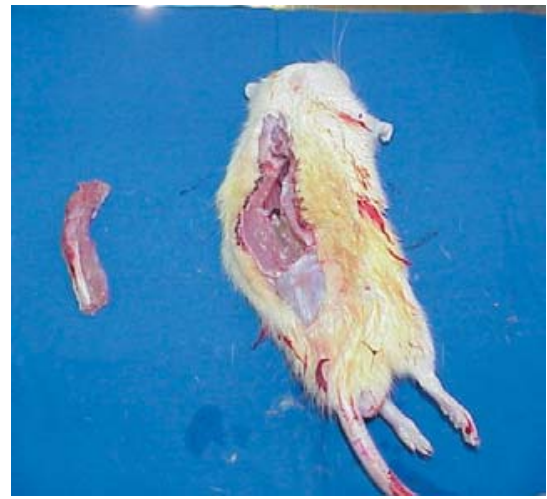

Figure 4 - Removal of the vertebral column from the C5 to L5 level.

\section{Necropsy}

After sacrifice, which occurred 48 hours after the spinal cord was damaged and fetal cell transplantation was performed, the animals were weighed and the identity and gender were confirmed. Then, the vertebral column and the spinal cord were removed.

Histological analysis of the transplanted spinal cord

Histological sections were obtained from the area of the spinal cord containing the transplanted cells. The magnitude of the injury and/or the presence, placement, and viability of the implanted cells were analyzed.

\section{RESULTS}

The breeding procedure resulted in 4 female rats with vaginal swabs positive for spermatozoids. They all became pregnant, and on day 14 of gestation, the rats underwent a cesarean section and were sacrificed.

After the production of the spinal cord injury, all the rats presented evidence of neurological deficits, which varied from complete monoplegia to complete paraplegia. The clinical finding of the magnitude of the spinal cord injury was later correlated with its histological finding.

All the rats were still alive 48 hours after the fetal cells transplantation. Also, there was no evidence of autophagia, pressure ulcers, or infection.

The histological analysis of the spinal cord sections relating to the site of the injury showed that the spinal cord damage resulting from the microdissection was not constant, varying from $40 \%$ to subtotal injury (Fig. 5). In 3 cases, a hematoma was found at the injured site, which was caused by a broken blood vessel (in this case, the anterior spinal artery).
The analysis of the histological sections showed the presence of the implanted fetal cells after a 48-hour period. However, in $40 \%$ of the cases, fetal cells were not identified at the site of the injury, but only in its trajectory (Table 1 and Fig. 6).

\section{DISCUSSION}

Traumatic spinal cord injury is one of the most disabling conditions occurring to man, which stimulates a strong interest in its histopathological, biochemical, and functional changes, mainly when we are searching for pre-

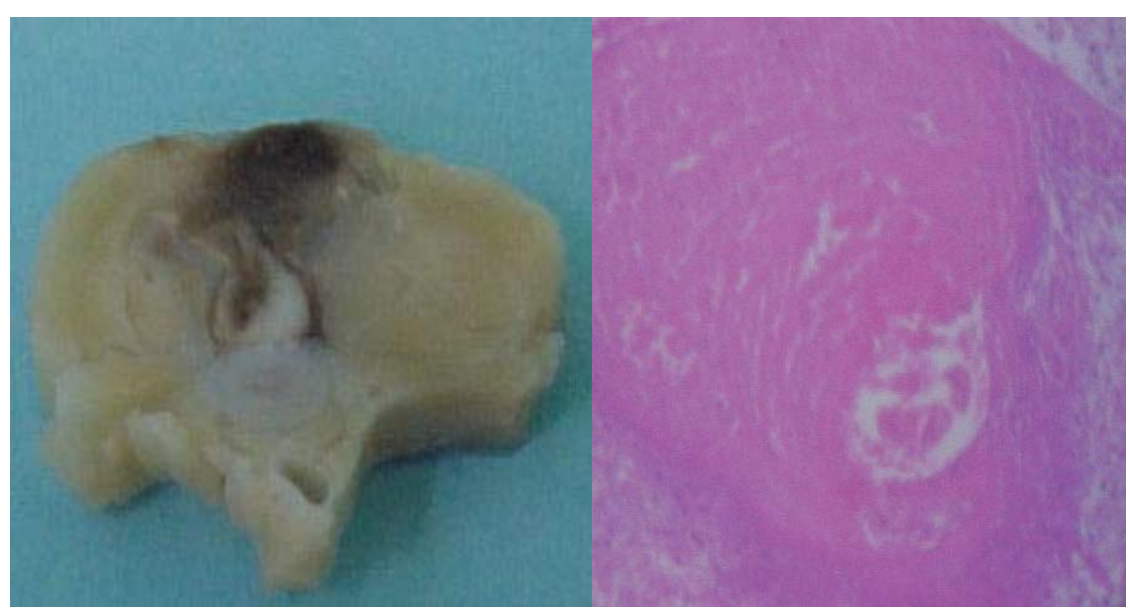

Figure 5 - A - Macroscopic section of the vertebral column showing the lesion and a hematoma in the trajectory of the lesion. B - Microscopic section showing the hematoma.

Table 1 - Viability and place of the fetal cells transplantation.

\begin{tabular}{cccc}
\hline RAT & $\begin{array}{c}\text { TRANSPLANTED FETAL } \\
\text { CELLS VIABLE }\end{array}$ & $\begin{array}{c}\text { TRANSPLANTED } \\
\text { CELLS }\end{array}$ & $\begin{array}{c}\text { AT THE INJURY SITE } \\
\text { AT THE INJURY } \\
\text { TRAJECTORY }\end{array}$ \\
\hline 1 & & & Yes \\
2 & Yes & Yes & Yes \\
3 & Yes & No & Yes \\
4 & Yes & Yes & Yes \\
5 & Yes & Yes & Yes \\
6 & Yes & No & Yes \\
7 & Yes & No & Yes \\
8 & Yes & Yes & Yes \\
9 & Yes & No & Yes \\
10 & Yes & No & Yes \\
11 & Yes & Yes & Yes \\
12 & Yes & Yes & Yes \\
13 & Yes & No & Yes \\
14 & Yes & Yes & Yes \\
15 & Yes & Yes & Yes \\
\hline
\end{tabular}



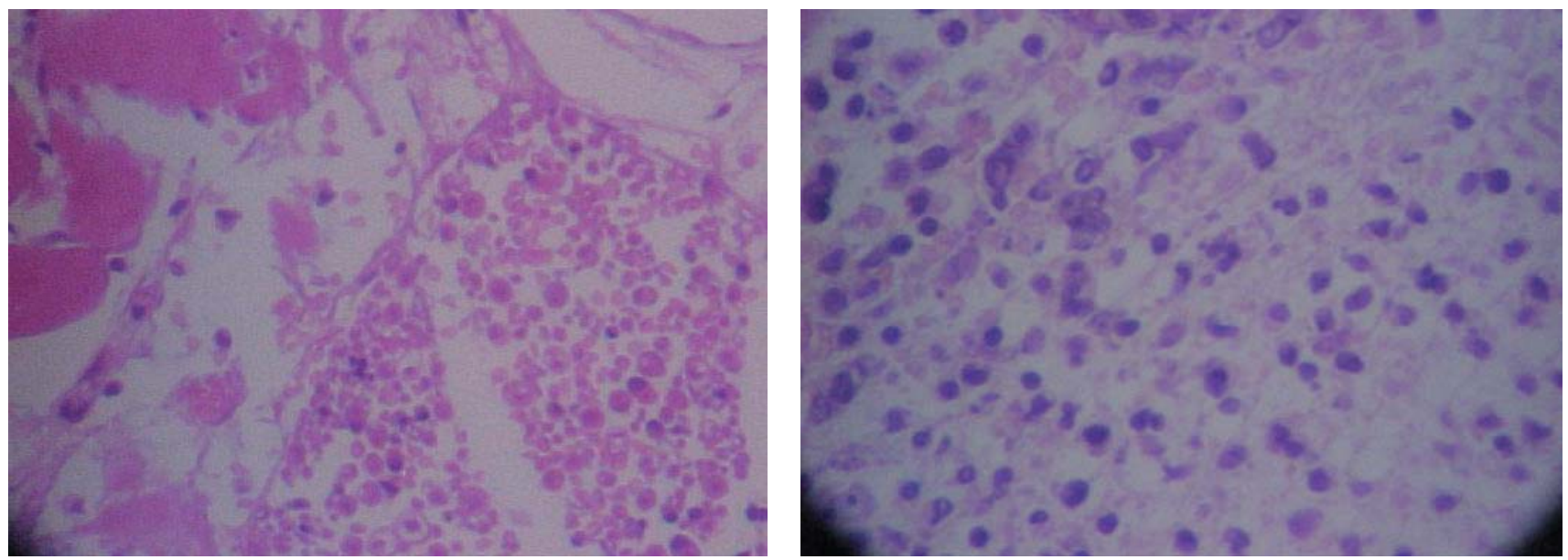

Figure 6 - A - A Microscopic section showing groups of fetal cells at the site of the injury. B - A smaller enlarged image of a section from a group of fetal cells at the site of the injury.

ventive and therapeutic methods for managing the sequelae of the spinal cord trauma.

For treating the spinal cord injury in man, experimental models are necessary for testing drugs, surgery techniques, and other therapeutic procedures, such as cell transplantation to the injured site. In the literature, there is not a universally accepted model of experimental spinal cord injury, which is attributable largely to different parameters that are analyzed and the significant diversity of therapeutic techniques that are tested.

Open experimental spinal cord injuries produce the best conditions for study. Closed injuries produce fractures whose fragments change the natural course that is intended for study. The spinal cord that is exposed can be directly sectioned or contused. Experimental methods that use different impacts as causative agents for the spinal cord injury include falling weights, crushing of the spinal cord using special tweezers for aneurysm ${ }^{57}$, extradural balloons that are gradually inflated, and damage caused by radiofrequency and microdissection. The ideal model would include the traumatic mechanism usually found in human beings, reproducibility, and the possibility of a quantitative analysis.
Nevertheless, such model has not yet been described.

We used a laminectomy technique and the $05-\mathrm{mm}$ microdissection of one half of the medula in this preliminary study, and we analyzed the placement and the viability of a $05-\mathrm{mm}$ segment of fetal CNS implanted into the site of the injury.

Although the microdissection was performed using a microscope, the histological analysis of the spinal cord injury showed evidence of differences in the magnitude of the injuries that were produced, which were usually larger than $50 \%$ of the spinal cord. These differences did not impair the objective of this study, which was to evaluate the histological presence of fetal cells 48 hours after the transplantation. However, for better standardization of the injury, subsequent studies will have to focus on the chronic phase of the injured spinal cord using functional evaluations through locomotion scales, electrophysiological, and pathological assessments.

We chose using Wistar rats because of their good availability and the minor technical difficulties in handling these animals. The preferred species for experiments involving spinal cord injury is one of the nonhuman primates, but their use is restricted due to high costs, little availability, handling difficulties, and ethical considerations $^{7}$. Rats are a good alternative in these experiments because their spinal cord has a cytoarchitectural organization and vascularization similar to that of humans?

Transplantation of cells from the central nervous tissue has been used for the past 20 years and has helped to increase understanding concerning the development of the nervous system and the neuronal response to injury. More recently, studies involving transplantation of cells from the central nervous system have been performed to restore or reduce the loss of function resulting from the injury. It has been proven that transplantation can reduce deficits or even increase the functional recovery following damage of the central nervous system, mainly in cases of degenerative diseases. Transplantation can influence the recovery of the function after the CNS trauma through several mechanisms including non-specific consequences of transplantation, trophic actions, hormone and neurotransmitter release, and more specific mechanisms involving re-enervation of host cells and establishment of reciprocal connections between the transplanted and the host tissue $e^{16,17}$. 
The requirements for anatomical and functional recovery after spinal cord injury are more complex than from other neurological damage, which usually requires only restoration of the neurotransmitter levels ${ }^{16}$.

There are several mechanisms through which the transplantation of fetal cells can affect the response to the injury and mediate the functional recovery after the injury. The transplanted fetal cells from the central nervous system are able to connect the spinal cord with the supraspinal structures through the site of the injury. The transplanted cells act as a substratum for restoring cellular communication between upper and lower levels of the injured tissues. At the cellular level, transplantation can supply trophic support either for mature or immature neurons, inhibit the formation of a glial scar at the site of the injury, and supply a favorable mechanical substratum of extracellular matrix for neuronal growth ${ }^{16}$.

Transplantation using cells from the central nervous system can improve the locomotor function after a spinal cord injury and provide a more complex microenvironment than that offered by peripheral nerve transplantation, cell suspensions, or genetically altered cells ${ }^{44}$.

In our study, the histological analy- sis of the injured site showed the presence of viable fetal cells in 9 of 15 rats (60\% of cases) that underwent the transplantation of fetal cells from CNS. In $40 \%$ of the cases fetal cells were not found at the site of the injury, but only in its trajectory.

This study showed the potential of a rat model of using transplanted fetal spinal cord cells that remain viable for 48 hours after their transplantation. Additional studies on the chronic phase of the spinal cord injury and the short- and long-term viability of fetal cells using functional assessments and histopathological evaluations are planned.
BARROS FILHO TEP de et al. Modelo experimental de transplante de células do sistema nervoso central fetal para lesão de medula espinal em ratos. Rev. Hosp.

Clín. Fac. Med. S. Paulo 57(6):257-264, 2002.

INTRODUÇÃO: A lesão traumática da medula espinal consiste numa das mais incapacitantes lesões que o ser humano pode sofrer e tem despertado grande interesse no conhecimento das alterações histopatológicas, bioquímicas, funcionais e principalmen- te na busca de métodos de prevenção e tratamento.

OBJETIVO: Propor um modelo experimental de transplante de células do sistema nervoso fetal de ratos para o sítio de lesão medular de ratos adultos que permitisse sua sobrevivência e integração para possibilitar protocolos de pesquisa para identificar outros fatores de regeneração e recuperação funcional pós trauma raquimedular.

MATERIAL E MÉTODOS: Utilizaram-se 15 ratos adultos que foram submetidos a laminectomia e lesão de $5 \mathrm{~mm}$ de hemimelula realizada com au- xílio de microscópio óptico. Os ratos tiveram seu sítio de lesão medular transplantado com células do sistema nervoso central de fetos de rato. Os ratos foram monitorados por 48 horas e tiveram sua coluna vertebral extraída para análise histológica.

RESULTADOS: Demostrou-se que em $60 \%$ dos casos as células transplantadas permaneciam viáveis no sítio da lesão.

DESCRITORES: Lesão medular. Células fetais. Ratos.

\section{REFERENCES}

1. ALLEN AR - Remarks on histopathological changes in spinal cord due to impact: An experimental study. J Nerv Ment Dis, 1914; 41:141-147.

2. ALLEN AR - Surgery of experimental lesions of spinal cord equivalent to crush injury of fracture dislocation. Preliminary report. J Am Med Assoc, 1911; 57:878-880.

3. ANDERSON DK, MEANS D \& SPEARS J - Spinal cord energy metabolism following compression trauma to the feline spinal cord. J Neurosurg, 1980; 53:375-380.
4. ANDERSON DK, MEANS D \& WATERS,TR - Microvascular perfusion and metabolism in injured spinal cord after methylprednisolone treatment. J Neurosurg, 1982; 56:106113.

5. ANDERSON DK, BRAUGHLER JÁ \& HALL ED - Effects of treatment with U-74006 on neurological outcome after experimental spinal cord injury. J. Neurosurg, 1988; 69:562567. 
6. BALENTINE JD - Hypotheses in spinal cord trauma research. In BECKER PB. Central Nervous System Trauma Status Report, $2^{\text {nd }}$ ed. NIH, 1985. p 455-461.

7. BALENTINE JD - Pathology of experimental spinal cord trauma. Lab Invest, 1978; 39:236-253.

8. BEGGS JL \& WAGGENER D - Transendothelial vesicular transport of protein following compression injury to the spinal cord. Lab Invest, 1976; 34:428-439.

9. BEHRMANN DL \& BEATTIE MS - Modeling of acute spinal cord injury in the rat: neuroprotection and enhanced recovery with methylprednisolone, U-74006F and YM-14673 high 1. Exp Neurol, 1994; 126:61-75.

10.BEHRMANN DL, BRESNAHAN JS, BEATTIE MS et al - Spinal cord injury produced by consistent mechanical displacement of the cord in rats: behavioral and histologic analysis. J Neurotrauma, 1992; 9:197-217.

11. BRACKEN MB - Pharmacological treatment of acute spinal cord injury: current status and future projects. J Emerg Med, 1993; 11:42-48

12.BRAUGHLER JM \& HALL ED - Current application of high-dose steroid therapy for CNS injury: A pharmacological perspective. J Neurosurg, 1985; 62:806-810.

13.BRAUGHLER JM \& HALL ED - Pharmacokinetics of methylprednisolone in cat plasma and spinal cord following a single intravenous dose of the sodium succinate ester. Drug Met Dispos, 1982; 10:551-552.

14.BRAUGHLER JM \& HALL ED - Lactate and pyruvate metabolism in injured cat spinal cord before and after a single large intravenous dose of methylprednisolone. J Neurosurg, 1983; 59:256- 261

15.BREASTED JH - The Edwin Smith Papyrus, In : BREASTED JH. Spinal Trauma. $1^{\text {th }}$ ed. Chicago, University of Chicago Press, 1930. p. 5

16.BREGMAN BS \& BAGDEN EK - Potential Mechanisms underlying transplant mediated recovery of function after spinal cord injury . In: MARWAH J, TEITELBAUM H, PRASAD KN. Neural transplantation, CNS neuronal injuries and regeneration. $2^{\text {nd }}$ ed. CRC Press Inc, 1994. p. 81-102.

17.BREGMAN BS \& REIER PJ - Neural tissue transplants rescue axotomized rubrospinal cells from retrogade death. J Compar Neurol, 1986; 244:86-95

18.CUELLO AC, GAROFALO L, KENIGSBERG RL et al. Ganglioside potentiate in vivo and in vitro nerve growth factor on central cholinergic neurons. Proc. Natl. Acad. Sci. USA, 1989; 86:2056-2060.

19.DE LEY G \& LEYBAERT,L - Effect of flunarizine and methylprednisolone on functional recovery after experimental spinal injury. J. Neurotrauma, 1993; 10:25-35.

20.DEMOPOULOS HB, FLAMM ES, PIETRONIGRO DD et al. The free radical pathology and the microcirculation in the major central nervous system disorders. Acta Physiol Scand, 1980; 492:91-119.
21.DENT LJB, MCCASLAND JS, STELZNER DJ et al. - Attempts to facilitate dorsal column axonal regeneration in a neonatal spinal environment. J Compar Neurol, 1996; 372:435-456.

22.DOHRMANN GJ, WAGNER FC, BUCY PC et al. - The microvasculature in transitory traumatic paraplegia. An electron microscopic study in the monkey. J Neurosurg, 1971; 35:263271.

23.DUCKER T \&, HAMIT HF - Experimental treatments of acute spinal cord injury. J Neurosurg, 1969; 30:603-607.

24.DUCKER T, SALEMAN M, PEROT PL et al. - Experimental spinal cord trauma: Correlation of blood flow, tissue oxygen and neurological status in the dog. Surg Neurol, 1978; 10:6063 .

25.DUSART I \& SCHWAB ME - Secondary cell death and the inflammatory reaction after dorsal hemisection of the rat spinal cord. Eur J Neurosci, 1994; 6:712-724.

26.FADEN AI \& SALZMAN S - Pharmacological strategies in CNS trauma. Trends Pharmacol Sci, 1992; 13:29-35.

27.FADEN AI, ELLISON JA, NOBEL LJ et al. - Effects of competitive and non-competitive NMDA receptor antagonist in spinal cord injury. Eur J Pharmacol, 1990; 175:165-174.

28.FADEN AI, JACOBS TP, HOLADAY JW et al. - Endorphins in experimental spinal injury: therapeutic effect of naloxone. Ann Neurol, 1982; 10:326-332.

29.GARCIA JL, LISTE L, TOBIO JP et al. - Intrathalamic striatal grafts survive and affect circling behaviour in adult rats with excitotoxically lesioned striatum. Neuroscience, 1995; 68:737749 .

30.GEISLER FH, DORSEY FC, COLEMAN WP et al. - Recovery of motor function after spinal-cord injury - a randomized, placebocontrolled trial with G1 ganglioside. N Engl J Med, 1991; 324:1829-1838, 1991.

31.GEISLER FH., DORSEY FC, COLEMAN WP et al. - Past and current clinical studies with G1 ganglioside in acute spinal cord injury. Annals Emergency Medicine, 1993; 22:108-114.

32.GOODKIN R \& CAMPBELL JB - Sequential pathological changes in spinal cord injury. Surgical Forum, 1996; 20:430-432.

33.GORIO A - Gangliosides as a possible treatment affecting neuronal repair processes. In: GORIO A. Advances in Neurology: Functional Recovery in Neurological Disease. $2^{\text {nd }}$ ed.. New York, Waxman Raven, 1988, p. 523-530.

34.GREEN BA \& WAGNER FC - Evolution of edema in the acutely injured spinal cord: a fluorescence microscopic study, Surg Neurol, 1973; 1: 98-101.

35.HALL E \& BRAUGHLER JM - Acute effects of intravenous glucocorticoid pretreatment on the in vitro peroxidation of cat spinal cord tissue. Exp Neurol, 1981; 73: 321-324.

36.HALL E - The effects of glucocorticoid and nonglucocorticoid steroids on acute neuronal degeneration. In: SELL, FJ. Advances in Neurology, $2^{\text {nd }}$ ed. New York, Raven, 1993. p. 241-248. 
37.HALL ED \& BRAUGHLER JM - Effects of intravenous methylprednisolone on spinal cord lipid peroxidation and $(\mathrm{Na}+$, $\mathrm{K}+)$ - ATPase activity. Dose-response analysis during the $1 \mathrm{st}$ hour after contusion injury in the cat. J Neurourg, 1982; 57:247253.

38.HALL ED, WOLF DL, BRAUGHLER JM et al. - Effects of a single large dose of methylprednisolone sodium succinate on experimental posttraumatic spinal cord ischemia: dose response and time-action analysis. J Neurosurg, 1984; 61:124-130.

39.HALL ED, McCALL JM, CHASE RL et al. - A nonglucocorticoid steroid analog of methylprednisolone duplicates its high-dose pharmacology in models of central nervous system trauma and neuronal membrane damage. J Pharmacol Exp Ther, 1987; 242:137-142.

40.HALL ED, YONKERS PA, ANDRUS PK et al. - Biochemistry and pharmacology of lipid antioxidants in acute brain and spinal and spinal cord injury. J Neurotrauma, 1992; 9: 425-442.

41.HALL ED - Effects of the 21-aminosteroid U74006 on posttraumatic spinal cord ischemia in cats. J Neurosurg, 1988; 68:462-465.

42.HERRICK M \& MILLS PE - Infarction of spinal cord. Arch Neural, 1971; 24:228-241.

43.HOLTZ AB, NYSTOM N, GERDIN B et al. - Spinal cord blood flow measured by ${ }^{14} \mathrm{C}$-iodoantipynne autoradiography during and after graded spinal cord compression in rats. Surg Neurol, 1989; 31: 350 .

44.HORNER PJ, POPOVICH PG, REIER PJ et al. - Fetal spinal transplant vascularity: metabolic and immunologic mechanisms. IN: MARWAH J, TEITELBAUM, H, PRASAD KN. Neural transplantation, CNS neuronal injuries and regeneration. $2^{\text {nd }}$ ed. CRC Press Inc, 1994. p. 81-102.

45.HOULE JD - Regeneration of dorsal root axons is related to specific non-neuronal cells lining NGF-treated intraspinal nitrocellullose implants. Exper Neurol, 1992; 118:133-142.

46.JANSSEN L \& HANSEBOUT RR - Pathogenesis of spinal cord injury and newer treatments. Spine, 1987; 14:23-32.

47.KAKULAS BA \& BEDBROOCK M - Pathology of injuries of the vertebral spinal cord-with emphasis on the microscopic aspects. In VINKEN PJ, BRUYN GW. Handbook of Clinical Neurology. Amsterdam, Elsevier, 1976. p. 2-42

48.KAKULAS BA \& TAYLOR JR - Pathology of injuries of the vertebral column and spinal cord. In:VINKEN PJ, BRUYN GW. Handbook of Clinical Neurology. Amsterdam, Elsevier, 1992, p. 21-51.

49.KARPIAK SE, WAKADE CG, TAGLIVIA A et al. - Temporal changes in edema, $\mathrm{Na}^{+}, \mathrm{K}^{+}$and $\mathrm{Ca}^{++}$in focal cortical stroke: G1 ganglioside reduces ischemic injury. J Neurosci Res, 1991; 30:512-520.

50.KARPIAKE SE - Ganglioside treatment after global ischemia protects changes in membrane fatty acids properties of $\mathrm{Na}^{+} / \mathrm{K}^{+}$ ATPase and $\mathrm{Mg}^{++}$ATPase. J. Neurosci Res, 1989; 28:402-412.
51.LUER MS, RHONEY DH, HUGHES M et al. - New pharmacological strategies in acute neuronal injury. Pharmacoterapy, 1999; 30: $58-69$.

52.MEANS ED, ANDERSON DK, WATERS TR et al. Effect of methylprednisolone in compression trauma to the feline spinal cord. J Neurosurg, 1981; 55:200-208.

53.NOBLE LJ \& WRATHALL,JR - Distribution and time course of protein extravasation in the rat spinal cord after contusive injury. Brain Res, 1989; 482:57-56.

54.REIER PJ, PERLOW MJ, GUTH L et al. - Development of embryonic spinal cord transplants in the rat. Develop Brain Res, 1983; 10:201-219.

55.REIER PJ, STOKES BT, THOMPSON FJ et al. - Fetal cell grafts resection and contusionlcompression injuries of the rat and cat spinal cord. Exper Neurol, 1992; 115:177-188.

56.RICHARDSON HD \& NAKAMURA S - An electron microscopic study of spinal cord edema and the effect of treatment with steroids, mannitol and hypothermia. Proc. Veterans Admin. 18th VA Spinal Cord Injury Conf, 1971; 18:10-16.

57.RIVLIN AS \& TATOR CH - Regional spinal cord blood flow in rats after severe cord trauma. J Neurosurg, 1978; 49:844-853.

58.SANDLER NA \& TATORCH - Effect of acute spinal cord compression injury on regional spinal cord blood flow in primates. J Neurosurg, 1976; 45:660-676.

59.SPILLER WG - A microscopic study of the spinal cord in two cases of Pott's disease. Bulletin of the Johns Hopkins Hospital, 1898; 9:125-133.

60.TATOR CH \& ROWED C - Current concepts in the immediate management of acute spinal cord injuries. Can Med Assoc J, 1979, 121:1453-1464.

61.TATOR CH, FEHLINGS MG - Review of secondary injury theory of acute spinal cord trauma with emphasis on vascular mechanisms. J Neurosurg, 1991; 75:15-26.

62.TESSLER A, FISCHER I, GIAZTER S et al. - Embryonic spinal cord transplants enhance locomotor performance in spinalized newborn rats. Advances in Neurology, 1997; 72:291-303.

63.WAGNER FC \& VANGILDER JC, - Pathological changes from acute to chronic in experimental spinal cord trauma. J Neurosurg, 1978; 48:92 -98.

64.WALKER JB \&, HARRIS M - G1 ganglioside administration combined with physical therapy restores ambulation in humans with chronic spinal cord injury. Neurosci Lett, 1993; 161:174178

65.WIRTH D, THEELE DP, MARECI TH et al. - In vivo resonance imaging of fetal cat neural tissue transplants in the adult cat spinal cord. J Neurosurg, 1992; 76:261-274.

Received for publication on December 12, 2001. 